\title{
The Larval Stages of Balcis alba and B. devians.
}

\author{
By \\ Marie V. Lebour, D.Sc., \\ Naturalist at the Plymouth Laboratory.
}

With One Plate.

THE young stages of the members of the family Eulimidæ are little known, the only reference to any species apparently being that of Loven (1844) who briefly notes and figures a veliger which he attributes to Eulima distorta (=Balcis devians). This has a very oblique shell and was probably a week or two old. A comparison of this figure with the apex of Balcis devians from Plymouth and its larvæ in the plankton makes one rather uncertain of its identity but shows that even in those early times it was known that a Eulima could remain some time in the plankton as a veliger.

\section{EULIMID平.}

\section{Genus Balcis.}

Balcis alba (da Costa) (=Eulima alba).*

(Plate I, Figs. 1-10.)

This is the commonest species of eulimid at Plymouth, being dredged frequently on the Mewstone Amphioxus ground, Mewstone Ledge and beyond the Eddystone. Several specimens were collected and placed in a plunger jar on the glass sides of which some of them laid eggs. The eggs are described here for the first time. The first batches were laid on March 10th, 1932, after which several more were deposited from April throughout the summer and also in the following years. No spawn has been seen in its natural surroundings.

The spawn case, or oötheca (Plate I, Fig. 1) is enormous for the size of the animal, measuring about $3 \times 2.5 \mathrm{~mm}$., the adult shell rarely reaching a length of $\frac{3}{4}$ inch. Oval, opaque with a very thick and tough skin of two layers, white, rounded on the free surface, flat on the under surface which is attached to some substratum, in this case the glass of the plunger jar. Inside are some hundreds of eggs although when newly laid they do not

* The names follow Winckworth's (1932) list, and the Plymouth Fauna List names (Marine Biological Association, 1931) are in brackets. Winckworth (1934) confirms his names in his later paper. 
PLATE I.
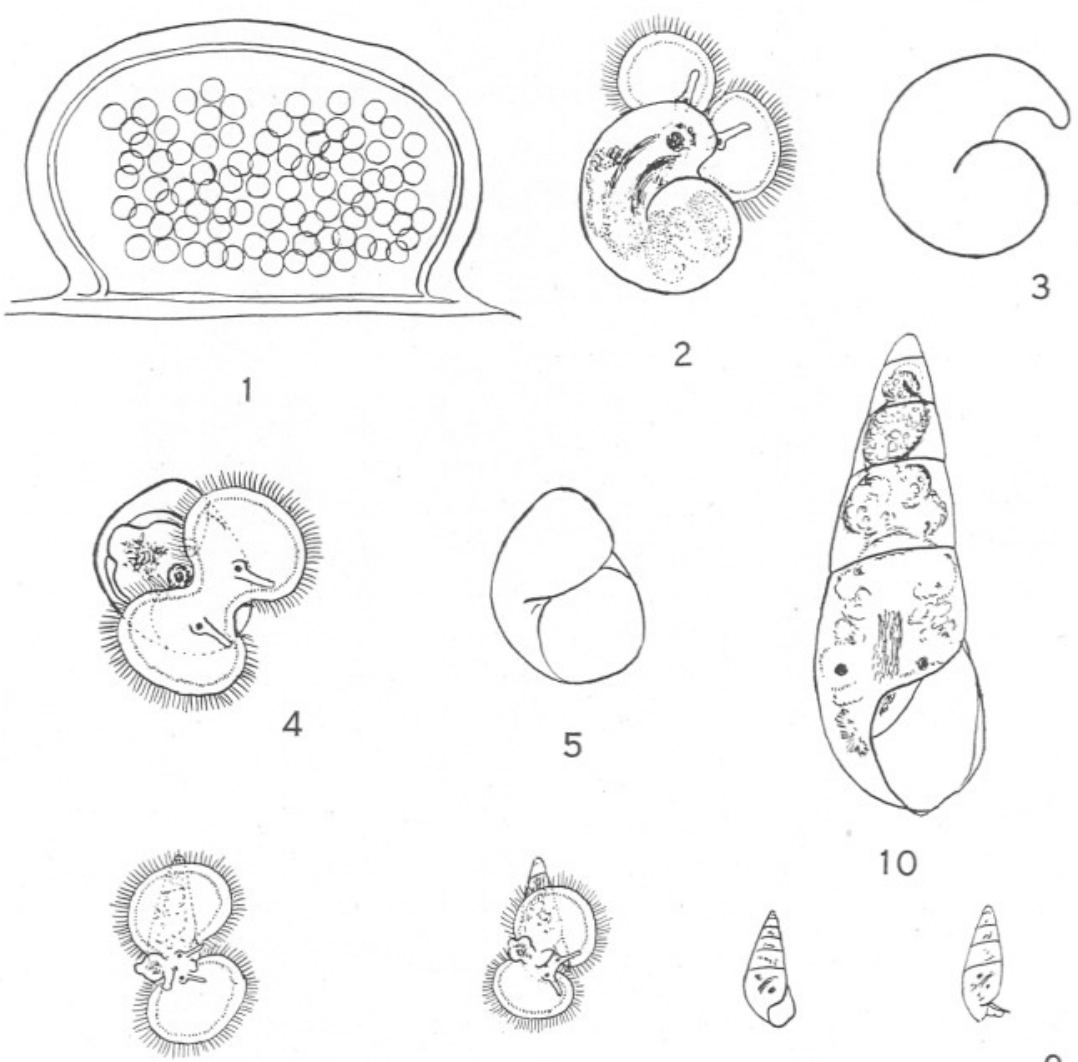

5

10

7
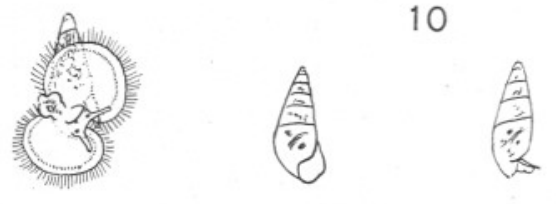

6

8
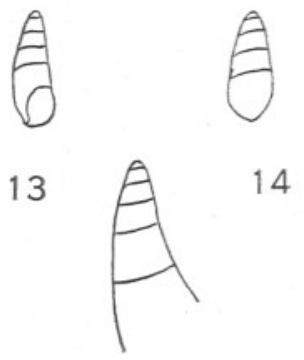

M

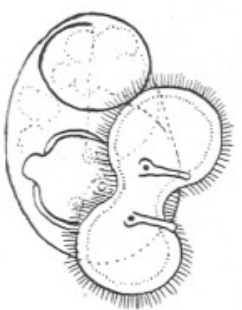

11

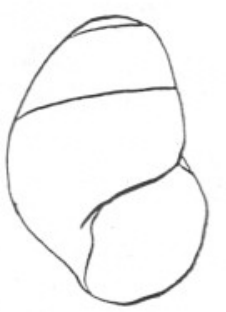

12

15 
nearly fill it, the space being filled with a liquid which is absorbed by the developing eggs. Eggs pinkish, at first about $0.10 \mathrm{~mm}$. across, rapidly enlarging to about $0.16 \mathrm{~mm}$. and hatching in about three weeks. Eggs laid on March 10th hatched on April 5th, other batches hatched in rather less time, some took rather longer. The newly hatched young were removed from the original plunger jar and placed in a fresh one with some pure Nitzschia culture for food. Unfortunately none of them lived for more than a few days. It was, however, possible to see the characters of the larvæ and compare them with those from the plankton. In this way one could distinguish them from those of closely related forms. The larvæ are common in the plankton, usually from outside the Sound, but occasionally from inside. The late veligers in particular occur frequently in summer (especially August and September) between stations L4 and L5 (in direct line towards the Eddystone) and over the Eddystone and Mewstone grounds. They remain for a long time as veligers attaining five whorls at least before losing the velum and retiring to the bottom.

The newly hatched larva (Plate I, Figs. 2, 3) measures about $0 \cdot 16$ to $0.18 \mathrm{~mm}$. across the shell and has about $1 \frac{1}{2}$ whorls. The apex is very broad and the larval shell resembles closely that of Pelseneeria stylifer (=Stilifer stylifer) hatched out in the Laboratory from eggs laid on Psammechinus (see Lebour, 1932), but the apex soon becomes more pointed (Plate I. Fig. 4). Pelseneeria is evidently closely related to the Eulimidæ, A striking feature of the larval Balcis alba is the deep black pigment running round the mouth and up the œsophagus (Plate I, Fig. 2) which continues for the whole of the larval life, the region of the digestive gland also being dark, the alimentary canal is forming, otocysts, eyes, tentacles, foot and operculum are conspicuous and the velum, measuring about $0.2 \mathrm{~mm}$. across is bilobed with round lobes (Plate I, Figs. 2, 4), and quite colourless. The outer lip of the shell is drawn out slightly into a process supporting the velum. The veligers in the plankton are of similar form and colour, with the spire gradually lengthening (Plate I, Figs. 6-10). The foot, tinted with black or dark grey, is three lobed, the region of the digestive gland dark and the black lines running towards the mouth very

\section{EXPLANATION OF PLATE.}

\section{PLATE I.}

FIG. 1.-Spawn of Balcis alba, laid on glass of aquarium, $3 \mathrm{~mm}$. across.

FIG. 2-3.-Newly hatched larva of Balcis alba, $0 \cdot 16 \mathrm{~mm}$. across shell (dorsal view).

Fig. 4-5.- Slightly older larvæ (ventral view).

Fig. 6-10.-Late larve of Balcis alba from plankton shell 0.66-0.72 mm. long. .

FIg. 11-12.-Young larva of Balcis devians from plankton shell $0 \cdot 24 \mathrm{~mm}$. long.

Figs. 13-14.-Late larvse of Balcis devians from plankton shell $0.64 \mathrm{~mm}$. long.

Fig. 15.-Apex of adult Balcis devians. 
conspicuous. As the apex lengthens the animal withdraws from the last whorl or two of the shell so that the first two whorls are usually empty in the older larvæ. When the shell has five whorls it measures about $0 \cdot 66$ to $0.72 \mathrm{~mm}$. in length, the dark grey foot has a long contractile fore part covering the mouth ventrally, the top of the animal below the two first whorls is dark and the velum still colourless with the lobes very round, usually unequal in size, the largest lobe being nearly equal to the length of the shell (Plate I, Figs. 6-7). At this late stage when the animal is about to metamorphose it is often found with the veligers of Cerithiopsis tubercularis, C. barleei and Triphora perversa (see Lebour, 1933), all of which correspond in size and form, having several whorls and bilobed velum with round lobes. The larva now loses the velum and crawls. The black pigment no longer shows in the adult which has a white body flecked with orange and yellow, especially round the head and tentacles, the foot also being white. The tip of the spire in the adult is nearly always broken off, the broken tip being filled up with calcareous matter.

\section{Balcis devians (Monterosato) $=$ Eulima phitippi.}

(Plate I, Figs. 11-15.)

This species is common among sponges and other sessile animals dredged in the Sound. It is well known for having a very much curved spire, but the first four or five whorls are quite straight, the curve only beginning apparently after the animal has lost the velum and taken to a life on the bottom. Larvæ attributable to this species are common in the inshore tow-nettings in spring and summer, especially July to September. They are much the same size as those of $B$. alba but without the black pigment in the animal, the spire of the shell being blunter and the apex usually not broken off in the adult as in that species. The adult is much smaller, about $10 \mathrm{~mm}$. or less in length. The digestive region in the larva is a pale yellowish brown, and the same colour shows through the shell of the adult which is very thin. The late larva has four or five whorls with a colourless velum with round lobes. The larva then loses its velum and goes down to the bottom.

This is the commonest eulimid in the inshore waters. A few other larvæ have been seen but not identified. They probably belong to Eulima pernula (=Strombiformis bilineata) and E. glabra (=Strombiformis glabra) (see Winckworth, 1934). These both occur at Plymouth, but are rare. Their spires are very slender and the larvæ would differ from those described above in this respect.

Judging from the two species described both larvæ must play an important part in the plankton, being common and remaining near the surface for a long time. 


\section{LITERATURE.}

Lebour, M. V. 1932. The Eggs and Larvæ of Two Commensal Gastropods, Stilifer-stylifer and Odostomia eulimoides. Journ. Mar. Biol. Assoc., N.S., Vol. XVIII, No. 1, pp. 117-122.

- 1933. The Life Histories of Cerithiopsis tubercularis (Montagu), C. Barleei Jeffreys and Triphora perversa (L.). Ibid., Vol. XVIII, No. 2, pp. 491-498.

Loven, H. 1844. Om nordiska Hafs-Mollusken. Oversigt af Kongl. Vetenskaps-Akademien förhandlingar, forste ărgăngen, pp. 48, 53.

Marine Biologrcal Association, 1931. Plymouth Marine Fauna, 2nd edition, pp. 1-371.

Winckworth, R. 1932. The British Marine Mollusca. Jour. of Conch., Vol. 19, No. 7, pp. 221-252.

— 1934. Names of British Mollusca. II. Ibid., Vol. 20, No. 1, pp. 11-15. 
